\title{
Dilema putus sekolah bagi anak-anak masyarakat tradisional di Jember, Jawa Timur
}

\author{
Miftakhuddin, Anwar Senen \\ Universitas Negeri Yogyakarta, Indonesia
}

\author{
A R T I C L E I N F O \\ Article history: \\ Received 01 Januari 2021 \\ Accepted 12 April 2021 \\ Available online 30 Juni \\ 2021 \\ Kata Kunci: \\ Dilema putus sekolah \\ Masyarakat tradisional \\ Jember \\ Keywords: \\ Drop-out dilemma \\ Traditional society \\ Jember
}

\begin{abstract}
A B S T R A K
Fenomena putus sekolah tidak selalu dijelaskan oleh teori-teori dan ilmu pengetahuan. Justeru, akan menjadi bagain dari ilmu pengetahuan itu sendiri. Beberapa kasus yang diuraikan di atas merupakan evidensi empiris asumsi tersebut. Bahwa putus sekolah sebenarnya bukan hanya tentang punya uang atau tidak punya uang, melainkan "diizinkan atau tidak diizinkan" oleh situasi dan kondisi. Sudah sepantasnya, bagi akademisi hendaknya turut mencari solusi atas berbagai masalah-masalah sosial, terutama yang menyangkut masa depan generasi penerus. Beberapa hasil penelitian di atas, menunjukkan bahwa sebaiknya kaum terpelajar tidak hanya cerdas secara intelektual, tapi harus cerdas secara sosial
\end{abstract}

\section{A B S T R A C T}

The phenomenon of dropping out of school is not always explained by theories and science. Thus, it will become part of science itself. Several cases described above are empirical evidence of this assumption. That dropping out of school is actually not just about having money or not having money, but "allowed or not allowed" by situations and conditions. It is appropriate for academics to participate in finding solutions to various social problems, especially those concerning the future of the next generation. Some of the results of the research above, show that educated people should not only be intellectually intelligent, but must be socially intelligent.

Copyright $($ o osfio. All rights reserved.

\section{Pendahuluan}

Program kewajiban belajar pertama kali dicanangkan pada 2 Mei 1984 dengan bentuk kewajiban belajar enam tahun pada tingkat SD atau sederajat. Perkembangan selanjutnya, ketika PP No. 28/1990 tentang pendidikan dasar disahkan, kewajiban belajar menjadi sembilan tahun. PP itu menyatakan bahwa pendidikan dasar terdiri dari program pendidikan enam tahun di SD dan program pendidikan tiga tahun di SMP (Mutrofin, 2009). Program pemerintah tersebut adalah bertujuan untuk menyelesaikan masalah pendidikan di Indonesia yang demikian kompleks, dan yang paling penting adalah masalah tidak meratanya pendidikan.

Sebuah kajian tentang Anak Putus Sekolah yang dilakukan bersama oleh Kementerian Pendidikan, UNESCO, dan UNICEF di tahun 2011 menunjukkan 2,5 juta anak Indonesia usia 7-15 tahun masih tidak bersekolah, dimana kebanyakan dari mereka putus sekolah sewaktu masa transisi dari SD ke SMP. Pengembangan kerangka kebijakan untuk merespon laporan itu, kemudian dilakukan di Jawa Tengah dan Jawa Timur, karena putus sekolah terkonsentrasi di sana (UNICEF, 2012). Sampai saat ini, menurut data dari Badan Pusat Statistik (2018a), menunjukkan angka partisipasi sekolah untuk Provinsi Jawa Timur adalah 99,57 untuk SD, dan 
96,77 untuk SMP. Sedangkan untuk SMA dan Pendidikan Tinggi, masing-masing adalah 71,51 dan 23.34. Angka-angka itu menujukkan bahwa semakin tinggi jenjang pendidikan, maka semakin rendah tingkat partisipasinya.

Rupanya, fenomena putus sekolah memang bukan "barang baru", tetapi upaya penyelesaiannya masih meninggalkan persoalan yang sama (Miftakhuddin, 2018b). Tahun 2008, di Kec. Kalisat dan Arajasa, Jember, terdapat 306 anak yang putus sekolah untuk menjadi buruh perkebunan (Latief et al., 2009). Sedangkan penelitian Miftakhuddin (2016) di Kab. Jember, menggunakan sampel anak putus sekolah sebanyak 15 orang, untuk melihat penyebab kultural ketidak bersekolahan anak. Bahkan pada tahun 2018, atas penelitian lanjutan oleh Miftakhuddin (2018) menujukkan masih ada putus sekolah, yang disebabkan oleh beberapa problem-problem dilematis, seperti benturan antara kewajiban bersekolah dengan kearifan lokal, isu difabelitas, sosial ekonomi, dan lain-lain. Tidak bersekolahnya anak, bisa berakhir menjadi beberapa hal, diantaranya: a) meunculnya pekerja anak (umumnya sebagai buruh kasar); b) kriminalitas dan anak jalanan; c) pernikahan dini; dan d) timbulnya buta aksara kembali. Manakala putus sekolah juga terjadi pada anak difabel, maka akan ada dampak lain berupa lestarinya hiperrealitas yang memandang bahwa anak difabel adalah golongan anak yang tidak mampu dalam banyak hal (Miftakhuddin, 2018a). Oleh karena itu, penting kiranya untuk mengidentifikasi kompleksitas persoalan yang dialami masyarakat, terutama masyarakat Jember tradisional yang cendrung berpandangan pragmatis.

Ada tiga alasan mendasar mengapa pembahasan menukik pada masyarakat Jember tradisional. Pertama, masyarakat tradisional mempunyai pengetahuan yang kurang terspesialisasi (Miftakhuddin et al., 2019), dan sedikit keterampilan yang diajarkan membuat mereka tidak perlu menciptakan institusi terpisah bagi pendidikan (sekolah). Sebagai gantinya, anak-anak memperoleh warisan budaya dengan mengamati dan meniru orang dewasa dalam berbagai kegiatan seperti upacara, berburu, dan pertanian (Waluya, 2012). Kedua, secara spasial, penting untuk dikaji karena antara satu wilayah dengan wilayah lain mempunyai perbedaan karakteristik. Keragaman karakteristik antar daerah inilah yang akan menentukan kualitas pendidikan pada daerah tersebut (Fitroni \& Zain, 2013). Ketiga, Indeks Pembangunan Manusia (IPM) Jember untuk tahun 2017 masih mencapai 64,96 (Badan Pusat Statistik, 2018b). Angka ini masih jauh dari kabupaten sekitarnya; Banyuwangi (misalnya), yang sudah mencapai 69,64 (Badan Pusat Statistik, 2018c). Identifikasi atas beberapa problmeatika tersebut akan dapat dimanfaatkan dalam pemetaan etnografi dan menuntun pada alternatif pemecahan masalah di atas.

\subsection{Rumusan masalah}

Rumusan masalah dalam paper ini ialah: (1) Mengapa mereka tidak bersekolah?, dan (2) Alternatif apa yang dapat diusulkan untuk mengatasi masalah tersebut?

\subsection{Tujuan penulisan}

Tujuan dilakukannya penulisan paper ini adalah: (1) Mengidentifikasi kompleksitas problematika putus sekolah pada masyarakat tradisional Jember, dan (2) Menemukan alternatif pemecahan masalah untuk persoalan-persoalan tersebut, utamanya yang dapat dilakukan guru jenjang Sekolah Dasar

\section{Hasil dan pembahasan}

Suyanto (2010) dalam bukunya berjudul Masalah Sosial Anak, merujuk pada dokumen PBB menegaskan bahwa anak putus sekolah termasuk dalam kategori anak rawan, yaitu anakanak yang karena situasi, kondisi, dan tekanan kultur maupun struktur menyebabkan mereka belum atau tidak terpenuhi hak-haknya. Bahkan kerap pula dilanggar hak-haknya. Inferior dan marginal adalah ciri khas dari anak putus sekolah, bersama-sama dengan anak rawan lain, seperti: pekerja anak, anak pengungsian perang dan bencana, anak melanggar hukum (kriminal), anak difabel, dan anak yang terdiskriminasi karena status sosial perkawinan keluarganya. 
Faktor-faktor penyebab putus sekolah pun sudah banyak terungkap oleh banyak penelitian, yang kerap kali bermuara ke dalam dua kategori (faktor internal dan eksternal). Katakanlah beberapa penelitian misalnya Latief et al., (2009), yang melaporkan bahwa faktor internalnya ialah ketiadaan motivasi bersekolah. Hal itu dipicu oleh faktor eksternalnya, yaitu pendidikan orangtua rendah, penghasilan keluarga rendah, dan lingkungan kultural; masyarakat dominan etnis Madura yang lebih suka mengaji daripada bersekolah. Sehingga tidak masalah jika putus sekolah asalkan tetap mengaji.

Rendahya pendapatan orangtua dan tingkat pendidikan orangtua, juga merupakan kesimpulan dari penelitian Dewi, Zukhri, \& Dunia (2014, dan Saputro (2009). Bahkan menurut penelitian Sudiyono (2010), sebesar 78,84\% orangtua anak menganggap bahwa sekolah kurang begitu penting. Tidak hanya sebatas itu, hasil penelitian Yuda (2012) menunjukkan faktor eksternal juga bisa berasal dari tidak adanya sarana dan prasarana yang memadai, serta kecacatan atau kelainan jiwa. Sedangkan faktor internal juga bisa pula disebabkan karena kemampuan akademik yang rendah (Ernita, 2016; Itsnaini, 2015).

Namun demikian, sebagaimana pernyataan Fitroni \& Zain (2013) di atas, aspek spasial penting untuk diperhatikan karena antara satu wilayah yang satu dengan wilayah lain mempunyai karakteristik masyarakat yang berbeda. Oleh karena itu, wilayah Jember pun juga mempuyai ciri khusus. Menurut survey, sebenarnya masyarakat Jember sudah mengerti betapa pentingnya pendidikan formal di sekolah untuk anak-anaknya. Situasinya sudah sangat berbeda dengan sepuluh tahun lalu saat dilakukan penelitian oleh Latief et al. (2009), yang mengatakan bahwa masyarakat etnis Madura lebih memprioritaskan kepentingan rohani-religi daripada kepentingan edukasi.

Kini sebagian besar mereka dapat menempatkan pendidikan dan pengajian ke dalam skala prioritas yang sama setingkat. Tetapi, pada kenyataannya masih ada putus sekolah yang disebabkan oleh beberapa hal yang sukar diurai. Beberapa hal itu menyangkut situasi kultural, personal, ekonomis, dan ketimpangan sosial. Faktor-fakto itulah yang membuat mereka bimbang dan harus memutuskan dengan penuh pertimbangan matang. Sebab, jika suatu kewajiban terpenuhi, maka kewajiban lain akan tertinggalkan.

\section{Kondisi Kultural dan Ekonomi}

Sebagian besar masyarakat Jember adalah masyarakat Pandhalungan, yaitu masyarakat yang mempunyai budaya produk akulturasi dan asimilasi dari kultur Jawa dan Madura (Setiawan, 2015; Yuswadi, 2005). Beberapa kawasan di Jember, juga masih merupakan etnis Jawa tulen, Madura tulen, bahkan ada juga etnis suku Using yang sebenarnya berbasis di Banyuwangi bagian timur. Tetapi secara kultural, etnis Madura lebih dominan. Sehingga dalam berbagai aspek kehidupan bermasyarakat di kawasan ini, lebih banyak merujuk pada kebiasaan dan adat-istiadat masyarakat etnis Madura.

Terkati dengan putus sekolah, ada hal unik sekaligus memilukan manakala kita masuk ke dalam masyarakat etnis Madura tulen. Terlepas dari sikap etnis Madura yang ramah, sopan, dan polos, mereka mempunyai kebiasaan semacam perjanjian tidak tertulis. Perjanjian yang dimaksud adalah perjanjian antara dua orang pemuda bersahabt karib untuk mengawinkan anaknya jika mereka sama-sama sudah punya anak laki-laki dan perempuan. Mereka berkewajiban untuk menhormati perjanjian itu dan menjaga anak-anak mereka agar tidak menyuakai orang lain sampai usia mereka cukup untuk dinikahkan. Bahkan jika usianya belum cukup, tidak jarang orangtua memalsukan dokumen ke KUA agar pernikahan dapat segera dilangsungkan secara sah (Suyanto, 2010).

Perjanjian semacam itu, sudah menjadi suatu hal yang jamak dijumpai dalam masyarakat etnis Madura. Andaikata ada salah satu pihak yang melanggar janji itu, maka dianggap menodai kehormatan dan bisa berujung menjadi carok. Kebiasaan inilah yang juga masih ada di Jember dan turut berkontribusi pada terjadinya putus sekolah.

Suatu kasus yang ditemukan Miftakhuddin (2016) dalam penelitiannya, seorang anak perempuan melangsungkan pernikahan sesaat pasca menamatkan pendidikan di SD, setelah sebelumnya di lamar oleh calon suaminya sejak kelas 5 SD. Pihak sekolah dalam hal ini tentu 
tidak bisa berbuat banyak karena menyangkut dengan perjanjian dua keluarga. Lebih-lebih, menyangkut suatu tradisi.

Anak perempuan itu, sebut saja bernama Juhairiyah, tidak mempunyai pilihan, kecuali merelakan dirinya menjadi pengantin di usia dini. Sebab kalau Juhairiyah menolak, akan terjadi pertengkaran dua keluarga (carok). Alih-alih menjalani pendidikan tinggi, Juhairiyah tidak berkesempatan menjalani pendidikan jenjang SMP, dan harus menjalani jenjang kehidupan yang lebih serius; berumah tangga.

Juhairiyah dalam hal pernikahan dini tidak sendiri, sebab seringkali juga dipacu oleh kondisi ekonomi keluarga. Masyarakat tradisional Jember, yang umumnya kurang mampu secara ekonomi, berpandangan bahwa dengan menikahnya seorang anak, maka ia bukan lagi menjadi tanggungjawab orangtuanya, melainkan menjadi tanggungjawab suaminya. Pernikahan adalah upacara yang juga menandai bahwa si anak telah sanggup mandiri. Padahal beberapa kasus perceraian (broken home), kematian, dan kemiskinan juga disebabkan oleh pernikahan dini.

Praktis, kondisi dilematis itu membentuk lingkaran masalah yang sukar dituntaskan; pernikahan dini untuk menghindar dari kemiskinan, dan kemiskinan memicu terjadinya pernikahan dini. Kondisi akan semakin buruk manakala tidak ada yang peduli terhadap mereka.

\section{Kondisi Personal}

Hampir sama dengan hasil penelitian (Purnama, 2015) di Pontianak, anak-anak mempunyai pemikiran pragmatis. Bagi mereka, sesuatu yang hasilnya tidak langsung nampak, maka dianggap sebagai kegiatan yang kurang bermanfaat dan kurang diprioritaskan. Sebagai pembanding, anak-anak kerap meninggalkan sekolah atau bolos untuk lebih memilih bekerja membantu orangtuanya di sawah, menjadi tukang parkir di kota, dan pekerjaan lainnya. Sebab dengan begitu, mereka akan langsung mendapatkan uang, daripada bersekolah yang tidak langsung mendapatkan uang untuk makan dan memenuhi kebutuhan sehari-hari. Namun disisi lain, mereka juga perlu bersekolah untuk bisa membaca, menulis, dan berhitung.

Orientasi kebendaan yang kental ini juga menjadi salah satu determinan dilema bagi anak untuk memilih apakah sebaiknya bersekolah, atau meninggalkan sekolah. Anak-anak juga kerap merujuk pada beberapa orang di sekitarnya yang bisa menjadi sukses dan kaya tanpa menyelesaikan sekolah. Seorang anak bisa saja berkata: "Haji Mansur itu tidak selesai sekolahnya dulu waktu SD, tapi sekarang sudah punya mobil, dua sepeda motor, dan empat ekor sapi".

Namun terlepas dari persepsi "optimis dan percaya diri" itu anak-anak penyandang difabel mempunyai ruang dilema tersendiri. Hasil penelitian Miftakhuddin (2018) menujukkan bahwa aspirasi bersekolah anak difabel sama ambisiusnya dengan anak normal. Hanya saja, pertimbangan utama dalam minat bersekolahnya adalah respon sosialnya yang cenderung diskriminatif. Semakin berat ketunaan anak difabel, biasanya akan semakin diskriminatif respon sosialnya. Katakanlah anak yang menderita tunadaksa, akan mendapatkan respon sosial yang lebih baik daripada anak difabel tunalaras.

\section{Ketimpangan lainnya}

Ada suatu penyebab putus sekolah yang disebabkan oleh suatu hal yang sepele dan bahkan tidak layak untuk dijadikan alasan untuk berhenti bersekolah, namun demikianlah adanya. Di Kecamatan Arjasa, ada sebuah MTs yang mempunyai bis antar jemput untuk siswasiswinya, melewati jalanan terjal, berkelok, dan naik-turun. Sementara sekolah lain, tidak mempunyainya. Bagi anak yang sekolahnya tidak mempunyai kendaraan atau fasilitas semacam itu, merupakan sesuatu yang sulit diterima oleh benak mereka. Kecemburuan semacam itu memang terkesan urusan remeh-temeh, namun bagi anak, hal itu adalah ketidakadilan.

Ketimpangan lain, adalah hilangnya motivasi bersekolah anak karena (bisa dibilang) tidak cocok dengan gaya mengajar gurunya. Anak itu, sebut saja bernama Habib, pernah dibentak dan dimarahi habis-habisan oleh guru Matematikanya karena ia tak kunjung memahami pelajaran yang disampaika oleh gurunya. Putus asa dan rasa jengkel terhadap sekolah merupakan dasar utama Habib mangkir dari program belajarnya. Sekalipun mendapat 
hukuman yang cukup berat dari orang tuanya, tidak mengubah keputusan Habib untuk meninggalkan sekolah. Praktis, kita tahu bahwa putus sekolah tidak melulu disebabkan oleh faktor ekonomi, sosial, dan budaya, melainkan juga bisa disebabkan oleh kompetensi pedagogis guru di sekolah.

4. Apa yang bisa dilakukan?

Selain dengan memperbaiki muatan pelajaran dan memperbaiki kualitas pembelajaran (Khoiron et al., 2020; Rahayu et al., 2019), terdapat beberapa alternatif pemecahan masalah yang dapat ditawarkan untuk meningkatkan angka partisipasi sekolah. Alternatif ini harus disesuaikan dengan karakteristik masyarakat dan penyebab utama masalahnya. Alternatif itu utamanya yang dapat dilakukan oleh guru di jenjang Sekolah Dasar. Beberap alternatif itu dijelaskan dalam uraian di bawah ini.

Pertama, pemberian beasiswa. Pemberian beasiswa yang dimaksud tidak harus berasal dari dana Bantuan Operasional Sekolah, namun dapat disalurkan menggunakan skema Siswa Asuh Sebaya (SAS), sebagaimana dilakukan oleh Pemerintah Kab. Banyuwangi. Gerakan itu dijalankan dengan menghimpun dana dari siswa yang lebih mampu untuk diberikan kepada siswa yang kurang mampu (Fanani, 2016).

Kedua, kelas inspirasi. Program yang semula digagas oleh Indonesia Mengajar ini cocok untuk diterapkan di sekolah dasar, karena karakteristik mereka yang sangat mudah untuk terpukau kepada sesuatu yang terlihat hebat. Menghadirkan orang-orang hebat yang meraih kesuksesan dengan bersekolah sampai tamat, adalah jalan terbaik untuk merekonstruksi struktur minat dalam benak anak.

Ketiga, penyuluhan di masyarakat. Cara ini utamanya menarget masyarakat dengan kebiasaan dan tradisi yang kurang progresif terhadap program-program pendidikan formal. Namun demikian, sekalipun bertajuk penyuluhan kegiatan ini harus tetap bersifat menghimbau dan anjuran; bukan mewajibkan apalagi menyalahkan sesuatu yang diyakini masyarakat sejak lama.

\section{Simpulan dan saran}

Fenomena putus sekolah tidak selalu dijelaskan oleh teori-teori dan ilmu pengetahuan. Justeru, akan menjadi bagain dari ilmu pengetahuan itu sendiri. Beberapa kasus yang diuraikan di atas merupakan evidensi empiris asumsi tersebut. Bahwa putus sekolah sebenarnya bukan hanya tentang punya uang atau tidak punya uang, melainkan "diizinkan atau tidak diizinkan" oleh situasi dan kondisi. Sudah sepantasnya, bagi akademisi hendaknya turut mencari solusi atas berbagai masalah-masalah sosial, terutama yang menyangkut masa depan generasi penerus. Beberapa hasil penelitian di atas, menunjukkan bahwa sebaiknya kaum terpelajar tidak hanya cerdas secara intelektual, tapi harus cerdas secara sosial.

\section{References}

Badan Pusat Statistik. (2018a). Angka partisipasi sekolah (APS) menurut provinsi, 2011-2017. https://www.bps.go.id/linkTableDinamis/view/id/1054

Badan Pusat Statistik. (2018b). Berita Resmi Statistik: Indeks Pembangunan Manusia Jember 2017.

https://jemberkab.bps.go.id/pressrelease/download.html?nrbvfeve=MTI1\&sdfs=ldjfdifsd jkfahi\&twoadfnoarfeauf=MjAxOC0xMS0yNyAyMzo0Mzo10A\%3D\%3D

Badan Pusat Statistik. (2018c). Tabel Indeks Pembangunan Manusia, BPS Jawa Timur. https://ipm.bps.go.id/data/kabkot/metode/baru/3500

Dewi, N. A. K., Zukhri, A., \& Dunia, I. K. (2014). Analisis Faktor- Faktor Penyebab Anak Putus Sekolah Usia Pendidikan Dasar Di Kecamatan Gerokgak Tahun 2012/2013. Universitas Pendidikan Ganesha.

Ernita. (2016). Pelaksanaan pendidikan agama islam pada keluarga remaja putus sekolah (studi terhadap keluarga etnis Banten di Kecamatan Medan Tembung Kota Medan. Institut Agama Islam Negeri Sumatera Utara. 
Fanani, A. (2016). Program Siswa Asuh Sebaya Banyuwangi Raih Penghargaan. Detik.Com. https://news.detik.com/berita-jawa-timur/d-3364586/program-siswa-asuh-sebayabanyuwangi-raih-penghargaan

Fitroni, B. N., \& Zain, I. (2013). Pemodelan Angka Putus Sekolah Usia Wajib Belajar Menggunakan Metode Regresi Spasial di Jawa Timur. Jurnal Sains Dan Seni Pomits, 2(2), 171-176.

Itsnaini, F. N. (2015). Identifikasi Faktor Penyebab Siswa Putus Sekolah Di Sekolah Dasar Kota Yogyakarta. Universitas Negeri Yogyakarta.

Khoiron, M., \& Wahyuningtyas, N. (2020, February). Revitalization of Social Studies Education: A Developmental Study Based on Dick and Carey Instructional Design. In International Conference on Social Studies and Environmental Issues (ICOSSEI 2019) (pp. 37-42). Atlantis Press. https://doi.org/https://dx.doi.org/10.2991/assehr.k.200214.007

Latief, M. A., Khutobah, Tasnim, Z., \& Rozaq, A. (2009). Faktor-faktor Penyebab Anak Usia Sekolah Pendidikan Dasar Tidak Bersekolah di Kabupaten Jember.

Miftakhuddin., Masyhud, M. S., \& Yuliati, N. Penyebab Putus Sekolah pada Anak Usia Sekolah Pendidikan Dasar Tahun 2013-2015 Ditinjau dari Perspektif Etnosains dan Cara Mengatasinya (Studi Kasus di Kec. Arjasa Kab. Jember Tahun 2016).

Miftakhuddin, M. (2018). Kecenderungan Putus Sekolah Difabel Usia Pendidikan Dasar di Jember. INKLUSI Journal of Disability Studies, 5(1), 95-114. https://doi.org/10.14421/ijds.050105

Miftakhuddin, M. (2019). Dedication of Unej Mengajar to Improve the Human Resources' Quality in the Retarded Areas of Jember through a Participatory Approach. Proceeding of Community Development, 2, 454-466. https://doi.org/10.30874/comdev.2018.1463

Miftakhuddin, A. M., \& Zulfiati, H. M. (2019). Misconceptions between Social Studies and Social Sciences among Pre-Service Elementary Teachers. International Journal of Education, 12(1), 16-25. https://doi.org/10.17509/ije.v12i1.17514

Mutrofin. (2009). Mengapa mereka tak bersekolah?: Evaluasi program kewajiban belajar. LaksBang.

Purnama, D. T. (2015). Fenomena Anak Putus Sekolah dan Faktor Penyebabnya Di Kota Pontianak. Universitas Tanjungpura.

Rahayu, L. P., \& Sartono, E. (2019, April). Self-Efficacy of Primary School Teachers in Mathematics Teaching: A Comparative Research on Teacher Training Program Products. In Elementary School Forum (Mimbar Sekolah Dasar) (Vol. 6, No. 1, pp. 68-78). https://doi.org/10.17509/mimbar-sd.v6i1.15122

Saputro, P. A. (2009). Faktor-Faktor Penyebab Anak Usia Sekolah Tidak Menyelesaikan Pendidikan Dasar (Studi Kasus di Desa Pesantren Kecamatan Blado Kabupaten Batang). Universitas Negeri Semarang.

Setiawan, I. (2015). Mengapa (harus) Pendalungan? Konstruksi dan kepentingan dalam penetapan identitas Jember. Matatimoer Institute.

Sudiyono, F. (2010). Karakteristik Orang Tua pada Siswa Lulusan SD Yang Tidak Melanjutkan Ke SMP Di Kecamatan Sumberbaru Kabupaten Jember. Universitas Negeri Surabaya.

Suyanto, B. (2010). Masalah sosial anak. Prenadamedia.

UNICEF. (2012). Laporan tahunan 2012.

Waluya, J. (2012). Pendidiikan dalam Masyarakat Tradisional dan Masyarakat Modern. UNISMA.

Yuda, D. C. K. (2012). Penyebab Anak- Anak Putus Sekolah dan Cara Penanggulanganya. Univeristas Negeri Malang.

Yuswadi, H. (2005). Melawan Demi Kesejahteraan, Perlawanan Petani Jeruk terhadap Kebijakan Pembangunan Pertanian. Kompyawisda. 